\title{
Beyond Postcoloniality: Female Subjectivity and Travel in Jamaica Kincaid's Among Flowers
}

\author{
Subarna Bhattacharya \\ Assistant Professor, Department of English, Symbiosis College of Arts and Commerce, \\ Pune, E-mail: subarna.bhattacharya@live.com
}

\begin{abstract}
In feminist studies, the relation between gender and travel has been addressed in many important critical discourses. Feminist critics have pointed out that travel writing had for long remained oblivious about women's travel, one reason being that travel was, forever, a masculinist exercise. Underlining the gendered aesthetics of travel writing, feminist criticism has read women's travelogues as interesting sites of struggle between repeating the normative patterns of male travelling and casting an 'alternative' gaze. However, reading women's travel writing simply as feminist narratives against their masculinist counterparts can be an oversimplification, as it may mean ignoring the deeper complexities underlying the texts. Being an autobiographical form, travel writing creates textual spaces where the formation of selfhood happens through a constant negotiation of the 'self with the 'world', not only in terms of gender, but also other subject identities like race, class, and culture. In this context, my paper proposes to read Jamaica Kincaid's Among Flowers. A Walk in the Himalaya (2005), as a female travel writing, where the question of gender intertwines with her non-white, ex-colonial, diasporic identity during her travel in Himalayan Nepal. My focus would be on examining the writer's narratorial self as a female agency, influencing, and negotiating her postcolonial identity. The paper will try to address how the travelogue functions as a register of female experiences, while Kincaid, as a post-colonial black traveller, negotiates her position within the existing imperialist paradigm of white travelling.
\end{abstract}

Keywords: travel, travel-writing, gender, feminism, postcolonialism

The history of travel and travel writing has for long remained oblivious about women's travel. Traditionally, the genre has suffered from acute gender imbalance, the primary reason being that travel has, forever, been viewed as a masculinist exercise and women's travel, as an act of nonconformity. For women, both travelling and engaging in writing about travel are transgressive. The relation between gender and travel has been addressed in many recent scholarly discourses on Feminism. A commonly held critical view is that women travel differently than men and, that, they write differently about their travel experiences. Women's travelogues have been read as registers of essentially feminine experiences, where, the travel is, more than anything else, an expression of liberation- an escape from domestic confinement. While men's travel writing engages more with the adventures and exploits of travel, women's travelogues are close inward examinations of the self. Thus, not only the act of travel but the writing about travel is also gendered. Moreover, for some women, travelling has been an act of performing masculinity. In conventional gender-terms, to step out of the comfort and safety of domestic boundary, and to

(C) AesthetixMS 2020. This Open Access article is published under a Creative Commons Attribution Non-Commercial 4.o International License (http://creativecommons.org/licenses/by-nc/4.o/), which permits non-commercial re-use, distribution, and reproduction in any medium, provided the original work is properly cited. For citation use the DOI. For commercial re-use, please contact editor@rupkatha.com. 
face the risks and dangers of travelling are performances of masculinity. However, if, on one hand, a recurrent feature in women's travelling is a pretension of travelling like men and appropriating the role of a male traveller, on the other hand, there is also a strong sense of anxiety to travel differently with an 'alternative' gaze, and to be dissociated from traditional male travelling. Women's travelogues are, therefore, interesting sites of struggle between repeating the normative patterns of travelling and improvising new and alternative ways of doing the same. However, it can be a dangerous over-simplification to read women's travel writing as simply feminist narratives against their masculinist counterparts, ignoring the other deeper complexities underlying the texts. As autobiographical writings, travelogues are expressions of the travellers' unique and complex subject-identities. Travelogues are textual spaces where the formation of the traveller-writers' individual selfhood happens through constant negotiations of the 'self with the 'world', not only in terms of gender, but also other identities like race, class, and culture.

In this respect, postcolonial travel writing of contemporary times is an interestingly dynamic field of study as the narratorial agencies, in these texts, are, most often than not, transnational, or transcultural, hybrid subjects. The role of travel writing, historically, has been one which facilitated the advance of the 'rhetoric of Empire' and enabled the Empire to further its colonialist expansionist projects. Edward Said's study of colonial discourses, in his influential book, Orientalism (1978) ${ }^{i}$ is an engaging foregrounding of the idea that the western representation of the 'East' or the 'Orient' in western writings, especially since the eighteenth century, was a construct, a careful 'othering' by which western imagination was able to find fixed 'object' positions for the subjects of the colonized places. Thus, according to Said, a wide range of Western texts, written about the Orient and produced during the colonial period, through their imagery, themes and motifs perpetuated an unequal power relation positioning the 'West' at a point of privilege from where it could represent the 'Orient', by denying it a subject position and tell its story, by muting the 'other'. Peter Hulme, in Colonial Encounters (1986) ${ }^{\text {ii }}$ refers to Said's idea of 'Orientalism' when he says:

Underlying the idea of colonial discourse, in other words, is the presumption that during the colonial period large parts of the non-European world were produced for Europe through a discourse that imbricated sets of questions and assumptions, methods of procedure and analysis, and kinds of writing and imagery, normally separated out into the discrete areas of military strategy, political order, social reform, imaginative literature, personal memoir and so on. (Hulme, 1986, p. 2)

Another seminal work in the studies of colonial discourse is Mary Louis Pratt's Imperial Eyes (1992) ${ }^{\mathrm{iii}}$, which sees travel writing as an ideological tool of the empire. It extensively discusses how travel writing of the colonial period adhered to and upheld a particular framework of knowledge and sustained it. Thus, critical engagements with the travel writings, produced at the time of the Empire, have underlined the importance of reading travelogues as important textual practices documenting the encounters between the Centre and the Periphery, the Metropolis, and the Colony. These critical engagements, as they mostly tried to read the logic of the Empire in travel works, have been heavily Eurocentric. However, past the colonial era, as travel writing moved from being primarily a West-dominated genre to one with instances of 'counter-travelling' or 'reverse travelling', where the traveller-writer is an ex-colonized subject, a transnational or a diaspora, there has been a growing sense of decentralization. In these new travel writings, the forms of selfhood that emerge resist the old binaries by articulating experiences of what may be called a 'reverse gaze'.In contemporary travel writing, few writers whose complex subjectpositions compel us to think about travel writing's restructuring of subject identities and 
reimagining of accepted binaries are Vikram Seth, Amitav Ghosh, Pico Iyer and Jamaica Kincaid, all of whose travel works are significant re-workings in the genre. Amongst these writers, Jamaica Kincaid's travel writing poses interesting challenges of reading, she being a woman travellerwriter, in the first place, and an ex-colonial subject and a diasporic national. Her travelogue, Among Flowers: A Walk in the Himalaya $(2005)^{\text {iv }}$ is a worthwhile study into how her female subjectivity intertwines with her non-white, ex-colonial, diasporic identities during her travelencounters in Himalayan Nepal. Travel writing is an essentially western genre, dominated by white bourgeois masculinity. In this context, Kincaid's travelogue raises several important questions, one of these being how far we can read the text as documenting resistance. As a register of female experiences, does the travelogue function as a cathartic narrative of liberation? Also, coming from an ex-colonial subject, does the text attempt to rewrite the stigmas attached to western travelling? As a post-colonial woman traveller, how does she address the question of travel within the existing imperialist paradigm of conquering, acquiring, and possessing? In my paper, I propose to look into these issues central to post-colonial women's travel writing through a reading of Kincaid's Among Flowers, a travel text containing complex discourses of femininity, gender identity, colonialism, and post-colonialism. Simultaneous presence of these discourses in the text questions the reading of the travelogue simply as a postcolonial travel writing and compels us to think how gender identity plays a key role in evolving the traveller-narrator's position as an ex-colonial subject in the text.

Among Flowers is a fascinating travelogue recounting the Antiguan-American writer's travel experiences in the Himalayas as a hiker, plant-gatherer, and seed-collector. She undertakes a journey from the United States to Nepal to join a group of peer-hikers on an expedition of seed collecting and plant hunting in the Himalayas. Kincaid's horticultural interests have been wellknown even before she took to write Among Flowers. My Garden (Book) (1999) is a book-length essay by her which, in the manner of subjective ramblings of one's mind, talks about her own garden in Vermont. Woven into the exploration of her emotional relationships with her garden are her observations how gardens, have, in general, had a close relation with the history of colonization. Thus, Kincaid's ideas of plant gathering and seed collection, as Western exercises of imperialist appropriation, have been fundamental in her narratives. Her writings repetitively building on her horticultural interests show how wilderness, nature, gardens, and nurseries have figurative presence in the framework of her imagination. Zoran Pecic, in his essay, Floral Diaspora in Jamaica Kincaid's Travel Writing (2011) ${ }^{\mathrm{vi}}$, discusses 'gardens' as having significant functions in the history of colonization and how Kincaid's text Among Flowers is 'both an act of resistance and a means for appropriating the Western institution of botany to voice untold stories of exploitation' (Pecic, 2011, p. 139). Pecic explores how the discourses, with 'gardening' as their central trope, can have multiple functions as discourses of power and dominion. Placing the idea in a post-colonial context, he uses Kincaid's travelogue as an example to illustrate how, during the travel, her post-colonial identity negotiates with her current position of belonging to the imperialist camp. My paper intends to move beyond reading Kincaid's text through only a postcolonial lens. It seeks to read the text as a female travel writing where feminine subjectivity is a nodal point in looking at the subject's ex-colonial, diasporic and hybrid identity. The focus, thus, would be on addressing the aspect of intersectionality and analysing how the writer's narratorial 'self, as a female agency, influences and negotiates her postcolonial identity in the text.

It is interesting to begin by looking at how the travel book, Among Flowers, took place. Kincaid recounts, on being asked to write a book about any place in the world she wished to be in, doing something of her choice, she immediately thought of southwestern China where she had once been on a seed hunting for her nursey. The idea, here, of going on a wild hunting to nourish 
one's garden back home is noteworthy. Garden is a symbol of domesticity, and gardening, an aesthetic endeavour, involving feminine acts of caring and nurturing. On the other hand, arduous travelling for seed gathering is a very masculinist enterprise, and the author, in calling seed collecting as seed hunting, is reiterating the imperialist masculinity of the project. Hence, if, on one hand, Kincaid adopts a masculinist role and functions within a masculine space (that of the unfriendly wild terrain of the mountains), simultaneously, she displays an essentially feminine subjectivity in imagining the conclusion of her travel in the secured comfort of her own garden. Apparently, her travel is an appropriation of the western masculine kind of systematic botanical surveys, in which important stimulants are intellectual curiosity and desire to achieve commercial gains. The narrative abounds in the rhetoric of western adventure travelling, guided by desires of acquisition and possession. She is in the company of three western travellers, her friend, Dan, and his two friends, Bleddyn and his wife, Sue, all of whom exemplify, in multiple ways, privileged travelling, so characteristically western. Bleddyn and Sue are gardeners and owners of prestigious nurseries, having come to collect seeds in Himalayan Nepal 'from as ideal a situation as can be in the temperate region of the prosperous world, Wales' (Kincaid, 2005, p.111). Dan is a seasoned nurseryman, an American plant gatherer, whose job frequently takes him on commercial seed collecting trips to places like Vietnam, Korea, Japan, and China and even, Chile and Guatemala. However, it is important to notice how these travellers envision their travelling in Himalayan Nepal in quite different ways and how Kincaid's desires and expectations from the travel significantly vary from the rest. Whereas the others are ardent hikers and seed hunters, Kincaid's expressions of love for pristine and idyllic nature during the long trails of a trek and her incessant longing to be surrounded by nature's own garden, speak of her intense desire for a romantic travel. Time and again she gives in to her visceral responses and intensely feminine bouts of emotions, instead of acting as a tough, proto-masculinist hunter-traveller, greedy for adventure. Such visceral responses even do not allow her to bond very well with her fellow female traveller, Sue. She confesses that while Dan and Bleddyn went seed hunting, it was expected of her and Sue to clean the seeds which have been collected the previous day. Whereas Sue is adept in sorting and cleaning the seeds, Kincaid is simply disinterested in such mechanical tasks. Rather she likes to indulge in 'being lost in amazement and awe' (Kincaid, p.20), as gazing romantically at the natural splendours seems to intermittently sweeten the monotony of her otherwise rugged and wearisome trek.

For women, choosing to travel may mean a deliberate denial of performing motherhood at home. The narrative opens a window to Kincaid's keenly feminine self when her motherly emotions prevail, and she is torn between her excitement of joining the trip and her grief of leaving her thirteen years old son, Harold, behind. The thought that he had wanted her to cancel her trip to stay back with him occupies her mind with feelings of guilt. For women travellers, accepting to neglect domestic responsibilities, especially that concerning children, and tiding over one's motherly emotions often are necessary preconditions to travelling. If, on one hand, crossing the threshold of the domestic, by transcending the restrictions or burdens of home, means a release, on the other hand, it is a negotiation within the very private space of one's 'self. It may involve justifying one's own choice to one's self as well as dealing with one's own sense of guilt. Often, during a travel, a feeling of guilt keeps haunting a woman subject's private moments of looking back at home. In case of Kincaid, her motherly emotions are triggered on several occasions. One of her porters is a fourteen years old Sherpa boy, Jhaba, who keeps reminding her of her son, Harold. She becomes particularly affectionate towards Jhaba and while parting, to her own surprise, rewards him way more than she does the other porters. 
Remembering home is a trope commonly used in travel writing. Memory functions as a mediating link between two spaces, one which is the subject's spatio-temporal site of travel, and the other, which the subject has left behind, and originally belongs to - that is the 'home'. In case of Kincaid, memory uses two particular kinds of associations to recall that space which is 'home' one, her son, Harold, and the other, her own garden in Vermont. It is worthwhile to examine how this going back and forth in time through a function of memory, operates in the narrative. For Kincaid, in the frame of her memory, her garden is a conspicuous presence. She confesses that throughout her travel in Nepal her own garden has never been absent from her mind. She has been all along carrying her home garden within her mental space:

I was making this trip with the garden in mind to begin with; so everything I saw, I thought. How would this look in the garden? This was not the last time that I came to realize that the garden itself was a way of accommodating and making acceptable, comfortable, familiar, the wild, the strange. (Kincaid, p.44)

Her garden in Vermont (which is present in the narrative as a function of her memory) is no less than a reflection of her female self. She finds in her garden a sense of fulfilment which comes through the actions of caring, nurturing and growing. Here, Kincaid's remark that the garden is 'a way of accommodating and making acceptable, comfortable, familiar, the wild, the strange' (Kincaid, p.44) needs to be read as her conception of what gardening is. It is not only a reflection of one's aesthetic sensibility but also the means to create, out of unfamiliarity, vastness and wilderness, something that is manageable, accessible and familiar; in other words, a very feminine way of drawing imaginary contour lines to transform the wild and the unfamiliar into the known and the familiar. Characterized by such essentially female aesthetics, Kincaid's perception and imagination of garden and gardening appear to be fundamentally different from that of her fellow traveller, Dan's.

Thus, although Kincaid aligns herself with her fellow western travellers and shares a common ground with them in their imperialistic seed hunting project, her seed collecting endeavours essentially revolve around the needs of her own garden and are not overtly guided by imperialist tendencies of commercial appropriation and possession, as is the case of the other travellers. She appears genuinely conscious about the appropriating nature of the whole travel and even makes self-reflexive confessions, like, 'Claiming, after all, was the overriding aim of my journey' (Kincaid, p.71). Such underlying ambivalences are unmistakable in the narrative, as she even overtly criticizes the imperialist nature of her own travel. In this regard, Debbie Lisle's observation about contemporary travel writing, in her book The Global Politics of Contemporary Travel Writing (2006) $)^{\text {vii }}$, may be referred to. According to Lisle, contemporary travel writing, even though it apparently embodies notions of cosmopolitanism, foregrounds little more than a continuation of the logic of Empire. The travel writing of the post-colonial era only illusorily abandons the colonial ideas of travelling, by seemingly embracing a globalised world of harmonious order or choosing to ignore imperialist notions of cultural difference. To distinguish between colonial-era travel writing and contemporary travel writing she uses the terms, 'colonial vision' and 'cosmopolitan vision' and argues that 'the cosmopolitan vision is merely a blander mutation of the colonial vision'(Lisle, 2006, p. 5).

In her book, Lisle discusses several contemporary travel writers like Paul Theroux, Bill Bryson, Eric Newby, V.S. Naipaul, Pico Iyer and Gary Younge to reflect on how their texts perpetuate hierarchical global relations by positing the narratorial 'self at a superior, privileged point at the cost of the 'other', that is, in other words, by constructing an inferior 'other'. In such travel works, the assertion of the difference with the 'other', if, on one hand, is a way of recognising cultural 
difference, in another sense, it is also a means of justifying the notion of superiority of the 'self over the lower 'other'. Such a sense of hierarchy is certainly implicit in Kincaid's travelogue also.

Furthermore, in case of women's travel writing, as Debbie Lisle observes, the narrator's gendered subject-position influences the identity/difference logic in a certain way. Clearly, as she says:

they don't want to fully adopt the hyper-masculine codes of the genre (for this would mean losing their unique status as 'women in a man's world'), but neither do they want to reverse that gaze and end up in a purely 'personal' tale of emotions, sentimentality and everyday detail (for this would disprove that they are tough enough to be included in the travel writing genre in the first place). (Lisle, 2006, p.123)

In Among Flowers, I argue, Kincaid's narrative is not simply a gendered gaze; the feminization of her gaze is a problematized reflection of her ex-colonial past and her hybrid subject-identity. Kincaid is an Antiguan American, whose early days have been spent in the formerly British colony of Antigua, a place with which she shares a unique love-hate relationship. Antigua features in many of her fictional works and most extensively in her non-fictional work, A Small Place $(1988)^{\text {viii. }}$. Based on Antigua, a tiny Caribbean island, with a history of colonial regime, the essay discusses how, even after decolonization, the place continues to suffer from exploitation by neocolonial forces, especially in the industry of tourism, something for which Kincaid strongly condemns the white European imperialist culture. Her ex-colonial identity and her first-hand knowledge of both the worlds are important determinants in shaping Kincaid's female selfhood in Among Flowers. In the travelogue, travelling to Himalayan Nepal becomes, for her, a travelling back in time and memory. It makes her stand face to face with herself and her past. In a particular instance, during her stay in the Thamel district of Kathmandu, she describes a scene through the window of her hotel:

People were bathing, washing their clothes, or filling up utensils with water. Because of my own particular history, every person I saw in this situation seemed familiar to me. But then again, because of my own particular history, every person I saw in the Thamel was familiar also. (Kincaid, p.18)

Interestingly, in her travel, the feeling of familiarity, with the so-called 'backward' worlds, is the cause of her own unease. It becomes a reminder of her personal fragility, the fact that, for her, the sense of 'home' is a divided space. Being an ex-colonial and a diaspora, her selfhood is a formation out of two different and incongruous experiences and her current site of travel is a spatialization of her past. Like most travel writings, the travel book, here, clearly echoes the myths of the Empire and reinstates the notions of geographical hierarchy of places. Debbie Lisle, while discussing the idea of temporalization of spaces, which pins geographical locations along an evolutionary queue of modernity, uses the term 'discourse of nostalgia' ${ }^{\text {,ix }}$, to refer to those travel writings which take the travellers, most often from privileged and advanced nations, to the socalled undeveloped parts of the globe. Narrated from a position of advantage, such travellerwriters' deliberate choice of 'backward' destinations, according to Lisle, is provoked by their nostalgia for a simplistic past, untouched by the imperial notions of modernity. Kincaid's position, in respect to such kind of travelling, is problematic to determine. In her case, the 'other' (that she encounters in Nepal) is a part of her 'self', which clearly complicates the binary of identity/difference. Far from inducing a romantic nostalgia, her travel reopens her past, evoking unsettling feelings of anxiety and loss, leading her to question her own position as a privileged traveller. Even suffering from an isolation within the group, the experiences of her travel situate her as equally distant from both the worlds - the privileged world of her white friends, Dan, Sue 
and Bleddyn, and the deprived world of the 'other', the porters, the natives and the local villagers. Thus, the self-reflexivity and the ironic ambivalences in the text, if, on one hand, are candid expressions of her femininity, on the other hand, they are manifestations of a colonized past buried in her. She suffers from a keen sense of self-consciousness that, through her travel, she is constantly representing a culture of which she is actually not a part.

The travelogue, thus, resists any single, linear, or monolithic reading. At one level, it reads as personal conundrums of a female traveller, as she wades through her feelings of agony, crisis, and loss, caused by the travel. However, in spite of its self-reflexivity, it will not be fully correct to categorize it simply as a female confessional narrative. Similarly, at another level, it appears as a travel narrative by a post-colonial subject, tacitly perpetuating the colonial legacy; that is, in hearing a colonialist rhetoric within an apparent cosmopolitanism (which Debbie Lisle observes to be an important characteristic of many contemporary travel works). After all, one may argue that she travels as a part of a group of first world travellers, with an irreconcilable difference with the peripheral culture. Though she is sensitive and mindful about the plight of the natives, she is unable to dissociate herself from the cushion comforts of the 'Western' world - the world she is lucky to be part of. But, even then, it is difficult to conclusively tell that all her unsettling feelings solely stem from a buried sense of guilt, as she plays the role of a wealthy patron of a metropolitan culture. In this respect, it is also important to examine how the indigenous people look back at her with particular interest - that is, what role does her racial identity play in the native's reciprocal gaze. In the text, she recounts how she can often guess that the natives are talking amongst themselves about her, 'sometimes it was the colour of my (her) skin, sometimes it was my (her) hairstyle' (Kincaid, p.63). Being familiar with seeing white-skinned people of European descent on such travels, 'they were not used to seeing people like me, someone of African descent,' (Kincaid, p.28), she says. Interestingly, in these ensuing dynamics of 'gaze' and 'reverse gaze', the normative binary of the two worlds are broken. The reverse-gaze of the natives becomes a reminder for her, of her past, her racial identity, and her hybrid subject-position. Probably, a question that arises in her mind is, do they see in her reflections of their own or is she still a part of the 'other' class?

Kincaid's travelogue, thus, articulates a different form of feminism than would commonly be expected from a female travel writing on mountain-hiking. Rather than challenging patriarchy or performing masculinity, her travel is feminized with the characteristic inward gaze of women's travelogues. The self-exploratory feminine quality of the narrative opens up space to lay bare the inherent contradictions in the traveller's own hybrid subject-position and the ambivalences and conscious hypocrisies of her counter-imperialist thoughts. Therefore, arguably, to read it just as a feminist travel account, carrying a female essence and foregrounding female experiences, or to evaluate it against some standard feminist norms of writing would leave numerous strands unexplored in the narrative. Similarly, reading it through the lens of post-colonialism is unduly fitting it into one single theoretical framework when the narrative demands more complex and discursive understanding. Women's travelogues, as a body of writing, are too dense and varied to be viewed uniformly within one coherent theoretical frame. Sara Mills, in her study of women's travel writing titled, Discourses of Difference $(1991)^{\mathrm{x}}$, commenting on the diversity of ideas within the corpus of women's travel writing, argues that a woman's travelogue can very well be partly feminist and partly masculinist, that is, it can be a feminist narrative intermittently adopting masculinist positions. Pointing out the limitation of viewing women's travel writing in isolation as just feminist texts, she discusses the importance of analysing the wider cultural-political discursive pressures working on women's travel texts, in several different ways to those on men's. Such isolated studies of women's travel writing, as texts informed by only the theoretical 
framework of feminism, has been described by Patrick Holland and Graham Huggan as 'essentializing women's travel writing' (Holland and Huggan, 20oo, p.113) ${ }^{\mathrm{xi}}$. Exposing the limitation of such studies, both Sara Mills and Patrick Holland and Graham Huggan have, therefore, concluded that women's travelogues can be in parts proto-feminist and in parts antifeminist; they may display, at the same time, colonial as well as anti-colonial attitudes. In the frame of these critical arguments, the inherent ambivalences in Kincaid's subject-position in Among Flowers and the narrative's characteristic genderfluidity become important considerations in understanding how the text addresses the theoretical discourses of postcoloniality and feminism.

\section{Endnotes}

${ }^{\mathrm{i}}$ Said, Edward. Orientalism. New York: Pantheon Books, 1978.

${ }^{\mathrm{ii}}$ Hulme, Peter. Colonial Encounters: Europe and the Native Caribbean, 1492 - 1797. London: Metheun, 1986. p. 2

iii Pratt, Mary Louise. Imperial Eyes: Travel Writing and Transculturation. London: Routledge, 1992.

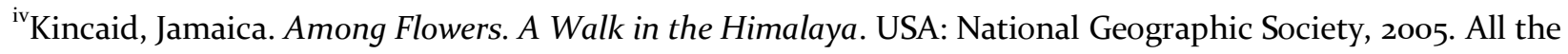
quotes from the text are from this edition.

${ }^{\vee}$ Kincaid, Jamaica. My Garden (Book):Farrar, Straus, and Giroux, 2001, first published in 1999. It is an essaycollection by Kincaid based on her gardening columns in New Yorker and other magazines like Architectural Digest and Travel and Leisure.

${ }^{v i}$ Pecic, Zoran, "Floral Diaspora in Jamaica Kincaid's Travel Writing" in Postcolonial Travel Writing. Critical Explorations. Eds.: Justin D. Edwards and Rune Graulund. UK: Palgrave Macmillan, 2011. pp 138 - 155.

${ }^{v i i}$ Lisle, Debbie. The Global Politics of Contemporary Travel Writing. Cambridge: Cambridge University Press, 2006.

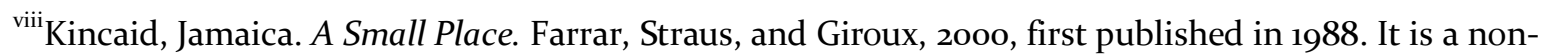
fictional prose based on Kincaid's growing up in Antigua. It contains her strong critique of the Antiguan government and her analysis of the problems that Antigua currently faces a former British colony, especially in the sector of tourism.

${ }^{\mathrm{ix}}$ Lisle, Debbie. The Global Politics of Contemporary Travel Writing. Cambridge: Cambridge University Press, 2006. pp. $203-259$.

${ }^{x}$ Mills, Sara.Discourses of Difference. An analysis of women's travel writing and colonialism. London and New York: Routledge, 1991.

${ }^{x i}$ Holland, Patrick and Huggan, Graham. Tourists with Typewriters. Critical Reflections on Contemporary Travel Writing. Ann Arbor: The University of Michigan Press, 2000.

\section{References}

Holland, Patrick and Huggan, Graham (200o). Tourists with Typewriters. Critical Reflections on Contemporary Travel Writing. Ann Arbor: The University of Michigan Press.

Hulme, Peter (1986).Colonial Encounters: Europe and the Native Caribbean, 1492 - 1797. London: Metheun. Kincaid, Jamaica (2005). Among Flowers: A Walk in the Himalaya. USA: National Geographic Society. 
9 | Beyond Postcoloniality: Female Subjectivity and Travel in Jamaica Kincaid's Among Flowers

Kincaid, Jamaica (2001). My Garden (Book): Farrar, Straus, and Giroux, first published in 1999.

Kincaid, Jamaica (2000). A Small Place. Farrar, Straus, and Girouxfirst published in 1988.

Lisle, Debbie (2006). The Global Politics of Contemporary Travel Writing. Cambridge: Cambridge University Press.

Mills, Sara (1991). Discourses of Difference. An analysis of women's travel writing and colonialism. London and New York: Routledge.

Pecic, Zoran (2011). "Floral Diaspora in Jamaica Kincaid's Travel Writing" inEdwards, Justin D. and Graulund, Rune (eds.) Postcolonial Travel Writing. Critical Explorations.UK: Palgrave Macmillan.

Pratt, Mary Louise (1992). Imperial Eyes: Travel Writing and Transculturation. London: Routledge.

Said, Edward (1978). Orientalism. New York: Pantheon Books. 